\title{
Gillian Bickley (ed), A Magistrate's Court in Nineteenth Century Hong Kong
}

Jean-Luc Rey

\section{OpenEdition}

1 Journals

Édition électronique

URL : http://journals.openedition.org/chinaperspectives/1873

DOI : 10.4000/chinaperspectives.1873

ISSN : 1996-4617

Éditeur

Centre d'étude français sur la Chine contemporaine

\section{Édition imprimée}

Date de publication : 15 avril 2007

ISSN : 2070-3449

\section{Référence électronique}

Jean-Luc Rey, «Gillian Bickley (ed), A Magistrate's Court in Nineteenth Century Hong Kong », China Perspectives [En ligne], 2007/2 | 2007, mis en ligne le 08 avril 2008, consulté le 21 septembre 2020. URL : http://journals.openedition.org/chinaperspectives/1873 ; DOI : https://doi.org/10.4000/ chinaperspectives. 1873

Ce document a été généré automatiquement le 21 septembre 2020.

(C) All rights reserved 


\section{Gillian Bickley (ed), A Magistrate's Court in Nineteenth Century Hong Kong}

Jean-Luc Rey

1 Gillian Bickley has for some time been interested in Hong Kong's early years as a British colony during the second half of the nineteenth century. She has more specifically centred on Frederick Stewart, whose life and prominent role during this period, notably in the establishment and development of Hong Kong's education system, have been the subject of several publications by herself and her husband, Verner Bickley, notably The Golden Needle: The Biography of Frederick Stewart (1836-1889) and The Development of Education in Hong Kong, 1841-1897.

2 If Frederick Stewart's role in the field of education is well-known and well-documented, it is less well-known that he also held the position of "Police Magistrate" for a brief period from 1881 to 1882 . The authors of Court in Time seize on this detail as the jumping-off point for a lively and engrossing illustration of Hong Kong society of the time as it appeared in accounts, published in the contemporary press (the Daily Mail), of judgments delivered by Frederick Stewart. The volume's contributors include a journalist and professor of Journalism, Tim Hamlett; a lawyer and former "Crown Counsel," Christopher Coghlan; a judge, Garry Tallentire, and a former Police Commissioner, Geoffrey Roper. Each author relies largely on his or her own experience in the territory of Hong Kong during and/or after the colonial era. This sort of "insider's view," gives Court in Time a remarkable authenticity, allowing authors to compare the state of affairs during Stewart's era with the situation they live or have lived with daily over the course of their careers.

3 The work is divided into two parts. The first consists of a series of articles analysing both the judge's role and his working conditions in Hong Kong at the end of the nineteenth century, while the second is devoted to transcriptions of selected accounts published in the China Mail of judgments delivered by Frederick Stewart. These are classified by theme (sailors, soldiers, policemen, prostitutes, pirates, etc.). Each section 
is accompanied by an introduction which offers lively sketches of life in Hong Kong at the time.

4 Court in Time presents its readers with a clear and precise picture of the operation of a Hong Kong court at the end of the nineteenth century, and more generally of the enforcement of public order and security in the British colony. The text is highly readable and accessible to non-specialists, thanks in particular to its educational emphasis and the almost systematic drawing of parallels with the present day. The work also offers, especially through the vivid snapshots provided by the accounts of the judgments, a lively and compassion-filled insight into the daily lives of the ordinary people who made up the core of Hong Kong's population some one hundred and twenty years ago. 